\title{
FAKTOR PENENTU KUALITAS LAYANAN PERBANKAN SERTA PENGARUHNYA TERHADAP KEPUASAN DAN LOYALITAS NASABAH PERBANKAN DI LAMONGAN
}

\author{
Dhita Dhora Damayanti \\ Fakultas Ekonomi, Universitas Islam Lamongan \\ dhitadhorad92@gmail.com
}

\begin{abstract}
ABSTRAK
Industri perbankan tidak hanya sekedar marketing dan menjual produk tetapi juga memberikan pelayanan kepada nasabah atau dapat disebut dengan bisnis trust. Hal ini berarti bank harus meyakinkan dan memberikan jaminan kepada nasabah dengan memberikan kualitas layanan sehingga menimbulkan kepuasan nasabah dan loyalitas nasabah. Bank harus menentukan faktor-faktor penentu kualitas layanan. Penelitian ini bertujuan untuk mengetahui faktor penentu kualitas layanan perbankan serta pengaruhnya pada kepuasan dan loyalitas nasabah di Lamongan. Data penelitian ini menggunakan kuisioner yang disebar pada 107 responden menggunankan purposive sampling dan menggunkan analisis faktor sebagai analisis statistik. Hasil dari penelitian ini ditemukan enam faktor kualitas layanan perbankan di Lamongan; daya tanggap, aksesbilitas, keandalan, bukti fisik, jaminan dan empati. Selain itu, kualitas layanan yang terbentuk dari enam faktor tersebut berpengaruh positif terhadap kepuasan nasabah dan kepuasan nasabah berpengaruh positif terhadap loyalitasa nasabah perbankan di Lamongan.
\end{abstract}

Kata kunci: kualitas layanan, kepuasan nasabah, loyalitas nasabah

\section{PENDAHULUAN}

Bisnis yang dijalani oleh industri perbankan adalah bisnis trust atau kepercayaan. Artinya bank perlu meyakinkan, memberikan jaminan dan menumbuhkan rasa percaya pada nasabahnya. Hal ini sangat berguna untuk meningkatkan kepuasan dan loyalitas nasabah pada bank. Mengingat begitu banyak bank yang ada di Indonesia yang bersaing untuk mempertahankan nasabahnya. Persa- ingan ini juga terjadi di bank-bank besar yang ada di Lamongan.

Oleh karena itu bank-bank yang ada di Lamongan harus bersaing dari sisi pelayanan agar mampu meraih pasar yang lebih besar. Mengingat begitu banyak bank-bank besar dan termasuk bank yang mampu mempertahankan loyalitas nasabahnya dan sedang bersaing di Lamongan.

Salah satu hal yang dapat dilakukan oleh bank adalah memberikan 
kepuasan untuk nasabah. Hal ini menjadi pertimbangan mengingat kepuasan dari seorang nasabah akan berdampak baik bagi bank karena dapat menimbulkan loyalitas dari nasabah untuk menggunakan bank tersebut.

Melalui fenomena tersebut, penulis tertarik untuk melakukan pengujian terhadap faktor-faktor apa saja yang menjadi penentu kulaitas layanan perbankan di Lamongan dan bagaimana pengaruhnya terhadap kepuasan dan loyalitas nasabah perbankan di Lamongan.

\section{TINJAUAN PUSTAKA}

\subsection{Kualitas Layanan}

Kualitas adalah sejauh mana produk atau jasa memenuhi spesifikasi spesifikasinya (Rambat, 2001). menurut (Smith, 1998) kualitas layanan adalah terpenuhinya kebutuhan dan ekspektasi dari konsumen. Parasuraman et.al (1988) mendefinisikan kualitas layanan sebagai sebuah bentuk penilaian yang timbul dari konsumen atas tingkat layanan yang diterima oleh konsumen tersebut (perceived service) terhadap tingkat layanan yang diharapkan oleh konsumen (expected service). Selain itu, Kualitas layanan telah diturunkan dari bidang pemasaran yang menilai interaksi manusia anntara bisnis dan pelanggannya yang mana hal ini berfokus pada hubungan antara harapan pelanggan atas layanan dan persepsi mereka tentang kualitas layanan yang diberikan. (Gronroos, 2007).

\subsection{Dimensi Kualitas Layanan}

Model ini berkaitan erat dengan model kepuasan. Dalam model Servqual, kualitas layanan didefinisikan sebagai penilaian atau sikap global yang berkenaan dengan superioritas suatu jasa (Parasuraman, et al,1985). Definisi pada tiga landasan konseptual utama, yakni:

1. Kualitas jasa lebih sukar dievaluasi konsumen daripada kualitas barang.

2. Persepsi terhadap kualitas jasa merupakan hasil dari perbandingan antara harapan pelanggan dengan kinerja aktual jasa.

3. Evaluasi kualitas tidak hanya dilakukan atas hasil jasa, tetapi juga mencakup evaluasi terhadap proses penyampaian jasa.

Dimensi kualitas layanan dibangun atas adanya perbandingan dua faktor utama, yaitu persepsi pelanggan atas layanan nyata yang mereka terima (Perceived Service) dengan layanan yang sesungguhnya yang diharapkan atau diinginkan (Expected Service). Jika 
kenyataan lebih dari yang diharapkan, maka layanan dapat dikatakan bermutu, sedangkan jika kenyataan kurang dari yang diharapkan, maka layanan dikatakan tidak bermutu. Apabila kenyataan sama dengan harapan maka layanan tersebut memuaskan. Dimensi kualitas layanan yang di rumuskan oleh Parasuraman, et al. $(1985,1988)$ biasa dikenal dengan dmensi SERVQUAL yaitu :

1. Daya tanggap, yaitu kemampuan untuk menolong pelanggan dari ketersediaan untuk melayani pelanggan yang baik.

2. Keandalan, yaitu kemampuan untuk melakukan pelayanan sesuai yang dijadikan dengan segera,akurat dan memuaskan.

3. Empati, yaitu rasa peduli untuk memberikan perhatian secara individual kepada pelanggan, memahami kebutuhan pelanggan serta kemudahan untuk dihubungi.

4. Jaminan, yaitu pengetahuan, kesopanan petugas serta sifatnya yang dapat dipercaya sehingga pelanggan terbebas dari resiko.

5. Bukti fisik, yaitu meliputi fasilitas fisik, perlengkapan karyawan dan sarana komunikasi.
Salah satu faktor yang menentukan kepuasan pelanggan mengenai kualitas jasa yang berfokus pada lima dimensi jasa. Kepuasan pelanggan, selain dipengaruhi oleh persepsi kualitas jasa juga ditentukan oleh kualitas produk, harga dan faktor-faktor yang bersifat pribadi serta yang bersifat situasi sesaat.

\subsection{Kepuasan Nasabah}

Kepuasan sebuah tingkat perasaan yang dimiliki seseorang setelah membandingkan kinerja atau hasil yang dirasakannya dengan apa yang telah diharapkannya. Kepuasan pelanggan juga dianggap dari perspektif kepuasan kumulatif dan didefinisikan sebagai pengalaman pelanggan secara keseluruhan dengan penyedia produk atau jasa (Johnson et al, 2001).

Ekspektasi konsumen atau nasabah dapat berasal dari beberapa hal yaitu: pengalaman pembelian masa lalu, nasihat teman dan rekan, serta informasi dan janji pemasar dan pesaing (Kotler, 2008).

Kepuasan nasabah akan meningkat saat layanan yang diberikan melebih inilai yang dirasakan pelanggan. Pertukaran informasi merupakan hal yang penting untuk memahami perubahan kebutuhan dan perilaku 
nasabah sehingga perusahaan dapat menyesuaikan produk untuk individu. Namun dengan syarat bank harus melindungi privasi pelanggan dan menghindari mengungkapkan data untuk pemasar dan dipengaruhi secara positif oleh kualitas layanan (Mei Mei Lau, 2013).

Kepuasan nasabah juga bisa didefinisikan sebagai sikap yang dihasilkan dari apa yang pelanggan percaya harus terjadi (harapan) dibandingkan denganapa yang mereka harapkan terjadi (persepsi kinerja) (Neal, 1998).

\subsection{Loyalitas Nasabah}

Konsep loyalitas pelanggan dan menciptakan pelanggan setia dalam bisnis digambarkan sebagai keterlibatan pelanggan dalam transaksi dengan organisasi tertentu dan barang membeli dan jasa dengan frekuensi sering. Dalam hal ini loyalitas adalah variabel yang berasal dari kepuasan pelanggan dan kinerja ekonomi (Susana dan Larson, 2004).

Loyalitas adalah komitmen yang dipegang secara mendalam untuk membeli atau mendukung kembali produk atau jasa yang disukai di masa depan meski pengaruh situasi dan usaha pemasaran berpotensi menyebabkan pelanggan beralih (Oliver dalam Kotler, 2008)

Menurut Maister dan Green yang dikutip dalam Hermawan Kertajaya (2012), untuk mendapatkan pelanggan yang loyal, maka bisnis yang berorientasi pada service atau jasa harus dilandasi dengan trust atau kepercayaan.

\section{METODOLOGI PENELITIAN}

\subsection{Rancangan Penelitian}

Rancangan penelitian yang digunakan pada penelitian ini didasari oleh beberapa klasifikasi (Cooper \& Schindler, 2008 : 142) yakni penelitian eksploratif dan eksplanatif karena disamping melakukan eksplorasi juga bertujuan menjelaskan hubungan kausal antar variabel melalui pengujian hipotesis, penelitian survei dengan menggunakan kuesioner sebagai alat pengumpulan data, penelitian cross sectional, penelitian primer dimana penelitian menggunakan data primer dan penelitian statistical study dimana penelitian menggunakan pengujian statistik dalam analisis data untuk memecahkan masalah penelitian. Dilihat dari hubungan antar variabelnya menurut Sugiyono (2011:10) penelitian ini 
termasuk penelitian kausal karena meneliti tentang sebab akibat.

\subsection{Identifikasi Variabel}

Dalam penelitian ini ada dua variabel bebas (X) yaitu Kualitas Layanan (X1) dan Kepuasan Nasabah (X2), tetapi pada uji hipotesis kedua variabel Kepuasan Nasabah menjadi variabel terikat (Y). Variabel lain adalah variabel terikat. Variabel terikat merupakan variabel yang dikenai pengaruh atau dipengaruhi oleh variabel bebas. Adapun varibel terikat pada hipotesis ketiga yaitu Loyalitas Nasabah (Y).

\subsection{Definisi Operasional dan}

Pengukuran Variabel

Berdasarkan pada identifikasi variabel dan dapat dilihat juga pada Gambar 1 dapat dijelaskan definisi operasional dari variabel-variabel dalam penelitian:

1. Kualitas Layanan, indikatornya adalah sebagai berikut:

a. Bukti fisik diukur dengan indikator : peralatan mutakhir atau modern, fasilitas fisik yang berdaya tarik dan nyaman,karyawan bank yang berpenampilan rapidan fasilitas fisik sesuai dengan jenisjasa yang ditawarkan.

b. Keandalan diukur dengan indikator : bila bank menjanjikan akan melakukan sesuatu pada waktu yang telahditentukan, pasti akan direalisasikan, bersikap simpatik dan sanggup menenangkan nasabah setiap ada masalah, jasa disampaikan secara benar semenjak pertama kali, jasa disampaikan sesuai dengan waktu yang dijanjikan dan sistem pencatatan yang akurat dan bebas kesalahan.

c. Daya tanggap diukur dengan indikator : kepastian waktu penyampaian jasa diinformasikan dengan jelas kepada para nasabah, layanan yang segera atau cepat dari karyawan bank, karyawan yang selalu bersedia membantu nasabah dan karyawan yang sanggup menanggapi permintaan nasabah dengan cepat dan tepat.

d. Jaminan diukur dengan indikator : karyawan yang terpercaya, perasaan aman sewaktu melakukan transaksi dengan karyawan, karyawan yang selalu bersikap sopan terhadap para 
nasabah dan karyawan yang berpengetahuan luas sehingga dapat menjawab pertanyaan nasabah

e. Empati diukur dengan indikator : perhatian individual dari bank, waktu beroperasi bank cocok atau nyaman bagi para nasabah karyawan yang memahami kebutuhan spesifik para nasabah, karyawan yang memberikan perhatian personal dan bank yang sungguh-sungguh

memperhatikan kepentingan setiap nasabah.

2. Kepuasan Nasabah dalam penelitian ini diukur dengan indikator : kepuasan nasabah ketika menggunakan layanan bank, kepuasan nasabah dengan keseluruhan layanan yang diberikan bank, kesan baik dan positif yang dimiliki nasabah terhadap kualitas layanan secara keseluruhan.

3. Loyalitas nasabah dalam penelitian ini diukur dengan indikator : pemilihan produk dan jasa dari bank yang sama oleh nasabah, pernyataan nasabah yang menyatakan loyalitasnya pada satu bank, kecenderungan nasabah untuk memilih layanan dari bank yang sama diantara bank-bank yang ada.

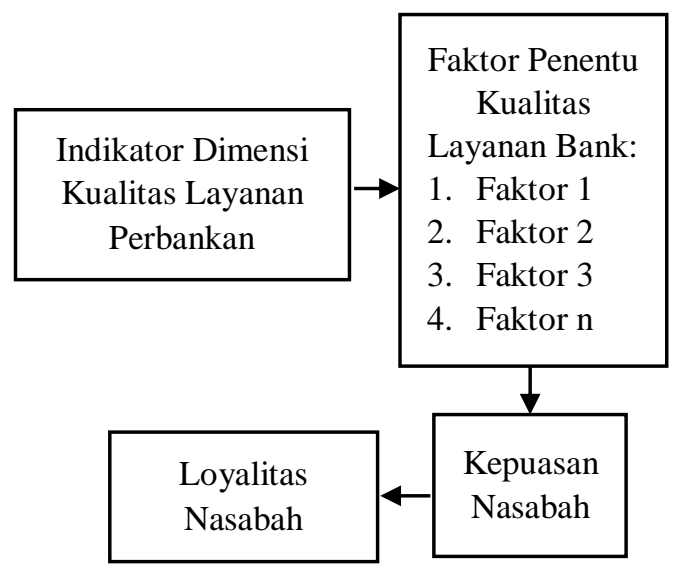

Gambar 1. Rerangka Penelitian

\section{HASIL PENELITIAN DAN PEMBAHASAN}

\subsection{Uji Validitas dan Reliabilitas}

Uji validitas adalah uji statistik yang digunakan untuk mengukur valid atau tidaknya suatu kuesioner (Sugiyono, 2011: 121). Pendekatan yang digunakan adalah Pearson Correlation dengan nilai sig $_{\text {hitung }}<0,05$ Uji reliabilitas merupakan alat statistik yang digunakan untuk mengukur suatu kuesioner yang merupakan indikator dari sebuah variable.

Uji reliabilitas dilakukan dengan pendekatan Cronbach Alpha dan dikatakan reliabel apabila nilai dari Cronbach Alpha >0.60. Uji validitas dan reliabilitas diujikan pada variabel kualitas layanan, kepuasan nasabah dan 
loyalitas nasabah pada 107 responden penelitian.

Berdasarkan hasil uji validitas dapat diketahui bahwa tingkat signifikansi atau sighitung untuk setiap item pernyataan yang ada pada sampel kecil pada masing-masing variabel memiliki nilai 0.000 atau memiliki nilai $\operatorname{sig}_{\text {hitung }}<0,05$. Berdasarkan hasil uji reliabilitas didapatkan variabel Kualitas Layanan memiliki nilai Cronbach's Alpha 0.925; Kepuasan Nasabah bernilai 0.714 dan Loyalitas Nasabah memiliki nilai 0.848 .

\subsection{Ringkasan}

Karakteristik

\section{Responden}

Responden merupakan nasabah bank BCA, Mandiri, BRI dan BNI yang ada di Lamongan dengan kriteria sekurang-kurangnya menjadi nasabah bank selama dua tahun dan memiliki frekuensi berkunjung minimal 2 kali dalam enam bulan terakhir. Sebesar $54.2 \%$ merupakan responden perempuan, berdasarkan usia $43 \%$ responden berusia 17-25 tahun, berdasarkan pekerjaan $33.6 \%$ merupakan wiraswasta/wirausaha/pengusaha.

Berdasarkan pendapatan $48.6 \%$ responden berada pada pendapatan kurang dari Rp 2.600.000, berdasarkan bank yang digunakan $37.4 \%$ menggunakan Bank BRI, berdasarkan layanan yang digunakan76.6\% responden menggunakan layanan simpanan pada bank, berdasarkan lama menjadi nasabah $55.1 \%$ responden telah menjadi nasabah bank selama 2 sampai dengan kurang dari 4 tahun dan berdasarkan frekuensi berkunjung $56.1 \%$ responden berkunjung 2 sampai 5 kali dalam enam bulan terakhir.

Tabel 1. Karakteristik Responden

\begin{tabular}{|c|c|c|}
\hline $\begin{array}{c}\text { Karakteristik } \\
\text { Responden }\end{array}$ & $\begin{array}{l}\text { Persentase } \\
\text { tertinggi }\end{array}$ & Keterangan \\
\hline $\begin{array}{l}\text { Jenis } \\
\text { Kelamin }\end{array}$ & $54.2 \%$ & Perempuan \\
\hline Usia & $43 \%$ & 17-25 tahun \\
\hline Pekerjaan & $33.6 \%$ & $\begin{array}{l}\text { Wiraswasta/ } \\
\text { Wirausaha/ } \\
\text { Pengusaha }\end{array}$ \\
\hline Pendapatan & $48.6 \%$ & $<\operatorname{Rp} 2.600 .000$ \\
\hline $\begin{array}{l}\text { Bank yang } \\
\text { digunakan }\end{array}$ & $37.4 \%$ & BRI \\
\hline Layanan & $76.6 \%$ & Simpanan \\
\hline $\begin{array}{l}\text { Lama } \\
\text { menjadi } \\
\text { nasabah }\end{array}$ & $55.1 \%$ & $\begin{array}{c}2 \text { sampai dengan } \\
\text { kurang dari } 4 \\
\text { tahun }\end{array}$ \\
\hline $\begin{array}{l}\text { Frekuensi } \\
\text { berkunjung }\end{array}$ & $56.1 \%$ & 2 sampai 5 kali \\
\hline
\end{tabular}

\subsection{Analisi Deskriptif}

Analisis deskriptif diperlukan untuk memberikan gambaran secara menyeluruh terkait dengan variabelvariabel penelitian dari sudut pandang 
jawaban yang diberikan oleh para responden yaitu nasabah perbankan di Lamongan. Tabel 2 akan menjelaskan hasil dari analisis deskriptif.

Berdasarkan Tabel 2 menunjukkan bahwa responden memberikan tanggapan setuju terhadap kualitas layanan bank dan berdampak pada kepuasan serta loyalitas nasabah perbankan di Lamongan.

Tabel 2. Hasil Analisis Deskriptif

\begin{tabular}{ccc}
\hline Variable & Rata-rata & Keterangan \\
\hline $\begin{array}{c}\text { Kualitas } \\
\text { Layanan }\end{array}$ & 3.935 & Setuju \\
$\begin{array}{c}\text { Kepuasan } \\
\text { Nasabah }\end{array}$ & 3.993 & Setuju \\
$\begin{array}{c}\text { Loyalitas } \\
\text { Nasabah }\end{array}$ & 3.813 & Setuju \\
\hline
\end{tabular}

\subsection{Analisis Faktor}

Sebelum melakukan lebih lanjut tahapan analisis faktor, perlu untuk memperhatikan nilai Barlett and KMO. Uji Barlett didapat nilai uji sebesar 1163.681 dengan signifikansinya 0,000 dan nilai $\mathrm{KMO}>0.5$ yaitu 0.868 .

Tabel 3. KMO dan Bartlett's Test

\begin{tabular}{|l|l|r|}
\hline \multicolumn{2}{|l|}{ Nilai } \\
\hline Kaiser-Meyer-Olkin Measure of & 0.868 \\
Sampling Adequacy. & \\
\hline Bartlett's & Approx. Chi-Square & 1163.681 \\
\cline { 2 - 3 } Test of & df & 210 \\
Sphericity & Sig. & 0.000 \\
\hline
\end{tabular}

Faktor yang terbentuk setelah dilakukan pengujian adalah sebanyak enam faktor dimana keenam faktor tersebut memiliki nilai eigenvalue lebih dari 1. Berikut merupakan faktor pembentuk kualitas layanan:

1. Daya Tanggap adalah faktor kualitas layanan yang mereprentasikan kemauan bank untuk membantu dan peduli pada nasabah dengan cepat dan tepat, memberikan informasi yang jelas pada nasabah, serta menekankan pada perilaku personal yang memberi pelayanan untuk memperhatikan permintaan, pertanyaan, dan keberatan dari para nasabah. Misalnya mengingatkan pada nasabah pemegang kartu kredit mengenai batas waktu pembayarannya, memberikan informasi yang jelas pada saat menjelaskan produk pada nasabah atau dengan memberikan pelayanan khusus pada nasabah prioritas.

2. Aksesbilitas. Faktor ini dapat dikatakan nasabah memiliki kemudahan untuk menghubungi dan mengakses pihak bank atau layanan bank. Hal ini berarti lokasi fasilitas jasa yang ditawarkan mudah dijangkau, waktu menunggu yang tidak terlalu lama bagi nasabah atau 
saluran komunikasi bank yang mudah dihubungi dan diakses oleh nasabah. Diharapkan bank mampu memberikan pelayanan yang prima, baik dari segi karyawan yang cekatan, meningkatkan pelayanan yang dapat diakses dengan mudah oleh nasabah sehingga hal ini dapat memberikan nilai yang lebih dan positif bagi bank dari nasabah.

3. Keandalan adalah faktor kualitas layanan yang menggambarkan kemampuan bank dalam memenuhi janji-janjinya. Fokusnya adalah pada keandalan dan keakuratan dalam pemenuhan janji pada nasabah. Misalnya ketepatan waktu dalam menemui nasabah, pelayanan yang sama untuk semua pelanggan, sikap simpatik dan akurasi yang tinggi.

4. Bukti fisik adalah faktor kualitas layanan yang memberikan fokus pada elemen-elemen pelayanan secara fisik. Pelayanan secara fisik ini bisa meliputi fasilitas-fasilitas, keadaan fisik, lokasi, teknologi yang digunakan, perlengkapan dan peralatan, sampai dengan tampilan fisik dari pegawai. Bank hendaknya mampu membentuk layout yang sesuai dengan jasa bank kepada nasabah, membuat banking hall yang senyaman mungkin bagi nasabah, mempekerjakan karyawan dengan penampilan yang menarik misalnya dari seragam yang baik atau memiliki fasilitas yang modern yang sesuai dengan jasa bank yang ditawarkan yang dapat menarik minat dan kepercayaan nasabah.

5. Jaminan adalah faktor kualitas layanan yang menggambarkan kemampuan bank untuk membentuk kepercayaan dan keyakinan pada nasabah yang dapat diberikan melalui pengetahuan yang dimiliki pegawai, kesopansantunan, dan kemampuan para pegawai dalam rangka menciptakan rasa percaya para nasabah kepada bank. Hal ini dikarenakan bank merupakan bisnis kepercayaan dimana nasabah memercayakan dananya pada bank untuk dikelola.

6. Empati adalah faktor kualitas layanan yang menjelaskan bagaimana memperlakuan nasabah sebagai individu sebagai wujud peduli, memiliki pengertian dan pengetahuan mengenai nasabah tersebut, memahami kebutuhan nasabah secara spesifik, serta memiliki waktu pengoperasian yang nyaman bagi nasabah. Hal yang 
perlu diterapkan pada layanan perbankan. Bank perlu mengetahui secara personal kebutuhan dan keinginan nasabahnya, pihak bank juga perlu membuat produk yang sesuai dengan cluster nasabah dimana bank tersebut berada.

\subsection{Pengujian Hipotesis}

Dalam melakukan pengujian hipotesis, dalam penelitian ini menggunakan Partial Least Square (PLS) yang mana hasil pengujian dapat dilihat pada Tabel 4.

Tabel 4. Hasil Uji PLS

\begin{tabular}{|l|l|l|l|l|}
\hline & $\begin{array}{l}\text { Path } \\
\text { Coef. }\end{array}$ & $\begin{array}{c}\mathrm{p} \\
\text { values }\end{array}$ & Sig & $\begin{array}{l}\text { Kepu- } \\
\text { tusan }\end{array}$ \\
\hline $\mathrm{KL} \rightarrow \mathrm{KN}$ & 0.465 & $<0.001$ & 0.05 & $\begin{array}{l}\mathrm{H}_{1} \\
\text { diterima }\end{array}$ \\
\hline $\mathrm{KN} \rightarrow \mathrm{LN}$ & 0.457 & $<0.001$ & 0.05 & $\begin{array}{l}\mathrm{H}_{1} \\
\text { diterima }\end{array}$ \\
\hline $\begin{array}{l}\text { R-squared } \\
\text { coefficients KP }\end{array}$ & 0.217 & \\
\hline $\begin{array}{l}\text { R-squared } \\
\text { coefficients LY }\end{array}$ & 0.209 \\
\hline $\begin{array}{l}\text { Average R-squared } \\
\text { (ARS) }\end{array}$ & 0.213 \\
\hline
\end{tabular}

Pengaruh Kualitas Layanan Terhadap

Kepuasan Nasabah

$\mathrm{H}_{0}$ : Kualitas Layanan tidak berpengaruh positif signifikan terhadap Kepuasan Nasabah Perbankan di Lamongan.

$\mathrm{H}_{1}$ : Kualitas layanan berpengaruh positif signifikan terhadap Kepuasan Nasabah Perbankan di Lamongan.

Berdasarkan hasil pengujian yang ada pada Tabel 4 menunjukkan jika nilai path koefisien adalah positif dengan nilai p-value <0.01 yang artinya kualitas layanan berpengaruh positif signifikan terhadap kepuasan nasabah. Oleh karena itu, hipotesis pertama atau $\mathrm{H}_{1}$ diterima. Kualitas layanan memberikan kontribusi terhadap kepuasan yang lebih besar. Hal ini berarti dengan adanya kualitas dalam melakukan pelayanan, bank dapat membentuk image dengan merumuskan strategi pemasaran yang diinginkan dan sesuai dengan kebutuhan pangsa pasarnya.

Hasil penelitian ini mendukung penelitian terdahulu yang dilakukan oleh Mei Mei Lau, Ronnie Cheung, Aris Y. C. Lam, Yuen Ting Chu (2013) yang menguji pengaruh kualitas layanan terhadap kepuasan nasabah yang dilakukan pada sektor perbankan. Adapun hasil yang diperoleh oleh penelitian tersebut mendukung penelitian ini yang menyatakan kualitas layanan memiliki pengaruh positif dan signifikan terhadap kepuasan nasabah. Menurut Gronroos (2007), kualitas layanan diturunkan dari bidang pemasaran yang menilai interaksi manusia antara bisnis dan pelanggannya yang mana hal ini berfokus pada hubungan antara harapan pelanggan atas layanan dan persepsi mereka tentang kualitas layanan yang 
diberikan. Dengan terpenuhinya harapan-harapan dari nasabah atas layanan yang diberikan bank hal ini mampu membuat nasabah puas. Secara keseluruhan responden memberikan penilaian yang positif tentang kualitas layanan yang diberikan oleh bank dan hal tersebut juga menyebabkan mereka menyatakan puas dengan pelayanan perbankan di Lamongan.

Pengaruh Kepuasan Nasabah terhadap Loyalitas Nasabah

$\mathrm{H}_{0}$ : Kepuasan Nasabah tidak berpengaruh positif signifikan terhadap Loyalitas Nasabah Perbankan di Lamongan

$\mathrm{H}_{1}$ : Kepuasan Nasabah berpengaruh positif signifikan terhadap Loyalitas Nasabah Perbankan di Lamongan.

Berdasarkan hasil pengujian yang ada pada Tabel 4 menunjukkan jika nilai path koefisien adalah positif dengan nilai p-value $<0.01$ yang artinya kepuasan nasabah berpengaruh positif signifikan terhadap loyalitas nasabah. Oleh karena itu, hipotesis pertama atau $\mathrm{H}_{1}$ diterima. Kepuasan memiliki keterkaitan yang erat dengan loyalitas. Kepuasan nasabah juga berpotensi memberikan sejumlah manfaat terhadap perusahaan, diantaranya salah satunya adalah berdampak positif terhadap loyalitas pelanggan (Fandy Tjiptono, 2008).

Penelitian ini mendukung hasil penelitian yang dilakukan oleh Mei Mei Lau, Ronnie Cheung, Aris Y. C. Lam, Yuen Ting Chu (2013) yang menguji pengaruh kualitas layanan terhadap kepuasan nasabah yang dilakukan pada sektor perbankan. Adapun hasil yang diperoleh oleh penelitian tersebut mendukung penelitian ini yang menyatakan kepuasan nasabah berpengaruh positif signifikan terhadap loyalitas nasabah. Dalam penelitian ini responden menyatakan setuju jika mereka merasa puas dengan layanan yang diterimanya dari bank. Baik dari tempat, layanan dan kesan positif terhadap keseluruhan pelayanan yang diberikan bank. Dengan terpenuhinya kepuasan nasabah, tentu akan menimbulkan rasa lebih dari puas yaitu loyalitas pada bank yang diwujudkan dengan tetap menggunakan bank yang sama, menjadi nasabah yang setia.

\section{PENUTUP}

\subsection{Simpulan}

Berdasarkan analisis dan pembahasan yang telah dibahas sebelumnya, maka dapat disimpulkan bahwa terdapat enam 
faktor penentu kualitas layanan perbankan di Lamongan yaitu Daya Tanggap, Aksesbilitas, Keandalan, Bukti Fisik, Jaminan dan Empati; kualitas layanan memiliki pengaruh positif signifikan terhadap kepuasan nasabah perbankan di Lamongan dan kepuasan nasabah memiliki pengaruh positif signifikan terhadap loyalitas nasabah perbankan di Lamongan.

\subsection{Keterbatasan Penelitian}

Adapun keterbatasan yang ada dalam penelitian ini yaitu (1) Adanya data dari responden yang tidak bisa dimasukkan dalam penelitian karena tidak masuk dalam kriteria pengambilan sampel (2) Kurang meratanya dalam mendapatkan responden dari empat bank yang menjadi obyek penelitian (3) Kurang meratanya jenis layanan bank yang digunakan oleh responden.

\subsection{Saran}

Dengan adanya hasil dan keterbatasan dalam penelitian ini, maka saran yang dapat diberikan kepada pihak bank yaitu (1) Bank di Lamongan diharapkan lebih tanggap dalam melayani nasabah dikarenakan faktor utama pembentuk kualitas layanan perbankan di Lamongan adalah faktor daya tanggap. Misalnya dengan memberikan pelayanan dengan cepat, mau dengan cepat merespon keluhan nasabah (2) Berdasarkan faktor fisik, hendaknya perbankan di Lamongan memberikan fasilitas dan fisik gedung yang menarik. Misalnya dengan membenahi banking hall, menyediakan kursi tunggu untuk nasabah mengantri, atau menambah jumlah mesin setor tunai maupun tarik tunai (3) Berdasarkan faktor keandalan, hendaknya pihak bank lebih bisa menepati janji-janjinya kepada nasabah dengan tepat waktu. Misalnya, pihak bank bisa menepati janjinya pada nasabah produk tabungan berjangka yang dijanjikan imbal jasa dengan tepat waktu dan imbal jasa yang diberikan sesuai dengan perjanjian.

Berdasarkan faktor daya tanggap, hendaknya bank lebih bisa menjelaskan kepastian waktu dalam penyampaian jasa. Dengan memberikan kejelasan pada setiap permasalahan yang dihadapi nasabah dengan baik, maka hal tersebut membuat nasabah akan lebih puas dengan pelayanan bank. (5) Berdasarkan faktor jaminan, hendaknya bank lebih menyiapkan sumber daya manusianya atau karyawannya dengan baik. Hal ini dimaksudkan agar karyawan bank memiliki pengetahuan yang luas, 
terutama hal-hal dibidang perbankan, dalam hal produk dan jasa yang akan ditawarkan pada nasabah.

Berdasarkan faktor empati, hendaknya bank lebih mendekatkan diri dengan nasabah, terutama nasabah yang memiliki frekuensi berkunjung lebih sering. Misalnya hafal dengan nama nasabah tersebut maupun memahami keperluan dan kebutuhan nasabah.

Bagi peneliti selanjutnya Bagi peneliti selanjutnya, disarankan untuk menambah variabel yang berkaitan dengan kepuasan nasabah dan loyalitas misalnya word of mouth marketing. Selain itu disarankan untuk menggali lebih banyak faktor pembentuk kualitas layanan dari beberapa sektor.

\section{DAFTAR PUSTAKA}

Cooper, Donald $\mathrm{R}$ dan Pamela $\mathrm{S}$.

Schindler. 2008.Business Research

Methods. Fifth Edition. New York.

Richard D Irwin Inc.

Dhyka Bagus Permana. 2011. Faktor-

Faktor Penentu Kualitas Jasa Perbankan Di Surabaya (Studi Komparasi Persepsi Nasabah Dan Karyawan). Journal of Business and Banking, Vol 1 (1): 75-84.

Fandy Tjiptono, 2006.Prinsip-Prinsip

Total Quality Service. Yogyakarta.

PenerbitAndi.
2008.Service

Management: Mewujudkan

Layanan Prima. Yogyakarta.

Penerbit Andi.

Gronroos, C. 2007. A service quality model and marketing implications. European Journal of Marketing, 18(4), 36-44.

Hermawan Kartajaya, Ardhi

Ridwansyah. 2011.Service with

Character: $18 \quad$ Prinsip

Keberhasilan Layanan di Era

Horizontal dalam Menciptakan

Loyalitas dan Rekomendasi

Pelanggan. Jakarta. Penerbit

Gramedia Pustaka Utama.

Imam Ghozali. 2014. Structural Equation

Modeling

:MetodeAlternatifdengan Partial

Least Squares (PLS). Semarang

:UniversitasDiponegoro

Imam Ghozali \& Hengky Latan. 2014.

Partial Least Squares :Konsep,

Metode dan Aplikasi. Semarang

:Universitas Diponegoro

Johnson, M.D. \& Gustafsson, A. \&Andreassen, T.W. \&Lervik, L. \& Cha. 2001. The evolution and future of nation customer satisfaction index models. Journal of Economic Psychology, 22(2), 217-245. 
Kotler, Philip dan Keller, Kevin Lane. 2008. Manajemen Pemasaran. Jakarta. Penerbit Erlangga.

Larson, S. \& Susanna, H. 2004. Managing customer loyalty in the automobile industry. Department of Business Administration and Social science.

Lau, Mei Mei, Cheung, Ronnie, Lam, Aris Y. C., Chu, Yuen Ting. 2013. Measuring Service Quality in the Banking Industry: A Hong Kong Based Study. Contemporary Management Research, Vol 9 (3): 263-282.

Majalah Infobank-Biro Riset Info Bank periode 2010 sampai dengan 2014. "Indonesian Bank Loyality Index (ILBI)". EdisiJanuari 2014. Jakarta.

Mistry, Snehalkumar H. 2013. Measuring Customer Satisfaction In banking sector: with Special Reference to Bank of Surat City.Asia Pacific Journal of Marketing \& management Review , Vol 2 (7): 132.

Neal, W. D. 1998. Satisfaction be damned, value drives loyalty. Diambil kembali dari http://www.sdrconsulting.com/article4.html
OJK. (t.thn.). Diambil kembali dari ojk.go.id:http://www.ojk.go.id/edu kasi-perbankan.

Parasuraman, A., Berry, L. L. \& Zeithaml, V. A. 1985. A conceptual model of service quality and its implications for future research. Journal of Marketing Research, Vol 49 (4): 41-48.

Parasuraman, A, Valarie A Zeithaml dan Leonard L Berry. 1988. SERVQUAL: A multiple-item scale for measuring consumer perceptions of service quality. Journal of Retailing, Vol 64:pp 1240.

Rambat Lupiyoadi, R. 2001. Manajemen Pemasaran Jasa: Teori dan Praktek. Jakarta: Salemba Emban Patrio.

Sellappan, R., Devi, P. Praba, \& Prabakar, C.R. 2013. Sevice Quality in Retailing, Banking and Insurance: A Comparative Study. Sona Global Magement Review, Vol 7(4): 40.

Smith, S. 1998. How to create a plan to deliver great customer service. New York, NY: AMACOM. 
Sugiyono. 2011. Metode Penelitian

Kuantitatif, Kualitatif dan $R \& D$.

Bandung: Penerbit Alfabeta. 